\title{
Karakteristik Pasien Tonsilitis Kronis pada Anak di Bagian THT-KL RSUP Dr. M. Djamil Padang Tahun 2013
}

Ivan Maulana Fakh ${ }^{1}$, Novialdi $^{2}$, Elmatris ${ }^{3}$

\begin{abstract}
Abstrak
Tonsilitis Kronis merupakan penyakit yang paling sering terjadi diantara semua penyakit tenggorok terutama pada anak. Penyakit ini terjadi karena adanya serangan lanjutan pada tonsil yang telah mengalami peradangan sebelumnya yang disebabkan oleh virus atau bakteri.Tonsilitis Kronis menempati urutan kedua tertinggi penyakit THT di Indonesia. Tujuan penelitian ini adalah mengetahui karakteristik tonsilitis kronis pada anak di Bagian THT-KL RSUP Dr. M. Djamil Padang. Penelitian ini bersifat deskriptif dengan Case Series yang dilakukan di RSUP Dr. M. Djamil Padang. Populasi adalah data pasien tonsilitis kronis dengan usia $<18$ tahun yang datang ke bagian poliklinik THT RSUP Dr. M. Djamil Padang sejak Januari sampai Desember 2013. Sampel diambil dari semua data rekam medis yang termasuk dalam populasi yakni sebanyak 50 sampel. Berdasarkan data rekam medis didapatkan pasien tonsilitis kronis pada anak paling banyak terdapat pada kelompok umur 10-14 tahun sebanyak 50\%, jenis kelamin perempuan sebanyak 56\%, keluhan utama nyeri menelan berulang sebanyak 56\%, ukuran tonsil T3-T3 sebanyak 68\%, penatalaksanaan secara operatif sebanyak $88 \%$. Kesimpulan studi ini ialah karakteristik pasien tonsilitis kronis pada anak paling banyak ditemukan pada perempuan dengan usia 10-14 tahun, memiliki keluhan utama nyeri menelan berulang dengan ukuran tonsil $\mathrm{t} 3-\mathrm{t} 3$, dan ditatalaksana dengan cara operatif.
\end{abstract}

Kata kunci: tonsilitis kronis, anak, keluhan

\section{Abstract}

Chronic tonsillitis is the most common disease among throats disease specially in children. Chronic tonsillitis happened because of recurrent inflammation in tonsil that caused by bacteria or virus. This disease is the second most common ENT disease in Indonesia. The objective of this study was to investigate the characteristic of chronic tonsillitis in children in Dr. M. Djamil Hospital in Padang. This was a descriptive study with case series design on medical records of tonsillitis chronic's patients from January until December 2013. The population of this study were tonsillitis chronic's patients with age <18 years old that came to ENT clinics in Dr. M Djamil Hospital. The 50 samples were taken from medical records. Based on medical records data, 50\% case happened in age 10-14 and female is the most common with 56\%, most of patients complains about recurrent pain in swallowing 56\%, tonsil size T3-T3 68\% and $88 \%$ operative treatment. The conclusions is the characteristics of the patients of chronic tonsillitis in children are mostly female with age between 10 to 14 years old, had a major complain about pain in swallowing, tonsil size T3-T3 and treated by operative treatment.

Keywords: chronic tonsillitis, children, complain

Affiliasi penulis: 1. Pendidikan Dokter FK UNAND (Fakultas Kedokteran Universitas Andalas Padang), 2. Bagian THT-KL FK UNAND/RSUP Dr. M. Djamil Padang, 3. Bagian Kimia FK UNAND Korespondensi: Ivan Maulana Fakh email: ivanm_fakh@ymail.com, Telp: 081267288799
Tonsil merupakan salah satu pertahanan tubuh terdepan. Antigen yang berasal dari inhalan maupun ingestan dengan mudah masuk ke dalam tonsil hingga

terjadi perlawanan tubuh dan bisa menyebabkan peradangan oleh virus yang tumbuh di membran mukosa kemudian terbentuk fokus infeksi. Keadaan ini
PENDAHULUAN

Jurnal Kesehatan Andalas. 2016; 5(2) 
akan semakin berat jika daya tahan tubuh penderita menurun akibat peradangan virus sebelumnya. Tonsilitis akut yang disebabkan oleh bakteri disebut peradangan lokal primer. Setelah terjadi serangan tonsilitis akut, tonsil akan sembuh atau bahkan tidak dapat kembali sehat seperti semula. Penyembuhan yang tidak sempurna akan menyebabkan peradangan ringan pada tonsil. Peradangan dapat menyebabkan keluhan tidak nyaman kepada penderita berupa rasa nyeri saat menelan karena sesuatu yang ditelan menyentuh daerah yang mengalami peradangan. ${ }^{1}$

Peradangan tonsil akan mengakibatkan pembesaran yang menyebabkan kesulitan menelan atau seperti ada yang mengganjal di tenggorok. Pada anak biasanya keadaan ini juga dapat mengakibatkan keluhan berupa ngorok saat tidur karena pengaruh besarnya tonsil mengganggu pernafasan bahkan keluhan sesak nafas juga dapat terjadi apabila pembesaran tonsil telah menutup jalur pernafasan. Jika peradangan telah ditanggulangi, kemungkin tonsil kembali pulih seperti semula atau bahkan tidak dapat kembali sehat seperti semula. Apabila tidak terjadi penyembuhan yang sempurna pada tonsil, dapat terjadi infeksi berulang. Apabila keadaan ini menetap, bakteri patogen akan bersarang di dalam tonsil dan terjadi peradangan yang kronis atau yang disebut dengan tonsilitis kronis. ${ }^{1}$

Tonsilitis kronis merupakan penyakit yang paling sering terjadi dari semua penyakit tenggorok yang berulang. Tonsilitis kronis umumnya terjadi akibat komplikasi tonsilitis akut, terutama yang tidak mendapat terapi adekuat. Selain pengobatan tonsilitis akut yang tidak adekuat, faktor predisposisi timbulnya tonsilitis kronis lain adalah higien mulut yang buruk, kelelahan fisik dan beberapa jenis makanan. ${ }^{2-4}$

Banyaknya faktor predisposisi timbulnya tonsilitis kronis juga berdampak pada banyaknya angka kejadian tonsilitis kronis. Seperti halnya pada penelitian Khan et al di RS Khyber Peshawar Pakistan pada periode April 2011 sampai dengan Mei 2012, dilakukan analisa tentang distribusi penyakit Telinga Hidung Tenggorok (THT) dan didapatkan 8980 orang menderita tonsilitis kronis $(27,37 \%)$ dari 32.800 total sampel. Dalam penelitian ini tonsilitis kronis berada di urutan teratas dari insiden penyakit THT lainnya. Tarasov dan Morozov juga melakukan pemeriksaan kesehatan pada anak dan dewasa, mendapatkan total penyakit THT berjumlah 190-230 per 1.000 penduduk, dan $38,4 \%$ di antaranya menderita penyakit tonsilitis kronis. $^{5,6}$

Menurut National Center of Health Statistics pada Januari 1997 di United States seperti dikutip oleh Edayu (2011), prevalensi penyakit tonsilitis kronis pada anak yang berusia di bawah 18 tahun didapatkan 24,9\% dari 1000 orang anak. Pada penelitian Khasanov et al di Rusia mengenai prevalensi tonsilitis kronis pada keluarga, didapatkan 335 anak usia 1-15 tahun dari 321 keluarga mengalami penyakit tonsilitis kronis. ${ }^{8}$ Menurut penelitian Kishve mengenai penyakit THT pada anak di salah satu rumah sakit di pedesaan India, penyakit Tonsilitis Kronis mayoritas terjadi pada anak perempuan (51,72\%), kelompok usia 5-14 tahun $(66,3 \%)$, berasal dari status sosial ekonomi rendah $(61,2 \%)$, dan memiliki ibu yang buta huruf $(70,8 \%){ }^{9}$

Di Indonesia, tonsilitis kronis juga menjadi salah satu peyakit THT yang paling banyak dijumpai terutama pada anak. $^{10}$ Penelitian Sapitri tentang karakteristik penderita tonsilitis kronis yang diindikasikan tonsilektomi di RSUD Raden Mattaher Jambi, dari 30 sampel didapatkan distribusi terbanyak usia 5-14 tahun (50\%), jenis kelamin perempuan $(56,7 \%)$ dan memiliki keluhan nyeri pada tenggorok/sakit menelan (100\%). ${ }^{11}$

Menurut data dari RSUD Raden Mattaher Jambi diketahui jumlah penderita tonsilitis kronis pada tahun 2010 berjumlah 978 dari 1365 jumlah kunjungan dan pada tahun 2011 berjumlah 789 dari 1144 jumlah kunjungan, sedangkan tonsilitis yang diindikasikan tonsilektomi pada tahun 2010 berjumlah 44 orang dan data pada tahun 2011 berjumlah 58 orang. Ada peningkatan jumlah penderita tonsilitis kronis yang diindikasikan tonsilektomi pada tahun 2010-2011 di RSUD Raden Mattaher Jambi. ${ }^{11}$ Berdasarkan data rekam medis tahun 2010 di RSUP dr. M. Djamil Padang bagian Poliklinik THT-KL subbagian laring faring ditemukan tonsilitis sebanyak 465 dari 1110 kunjungan. $^{12}$

Angka kejadian tonsilitis kronis meningkat dari tahun ke tahun. Insiden tonsilitis kronis juga paling banyak terjadi pada anak. Khususnya di daerah Padang Sumatera Barat, sampai saat ini masih belum didapatkan data yang pasti tentang karakteristik 
penderita tonsilitis kronis khususnya pada anak, karena itulah penulis tertarik untuk melakukan penelitian mengenai karakteristik penderita Tonsilitis Kronis pada anak di bagian THT-KL RSUP Dr. M. Djamil Padang periode Januari - Desember 2013.

\section{METODE}

Penelitian ini dilakukan di RSUP Dr. M. Djamil Padang dari Juli - Oktober 2014. Populasi penelitian adalah data pasien tonsilitis kronis yang datang ke bagian poliklinik THT-KL RSUP Dr. M. Djamil Padang sejak Januari - Desember 2013. Sampel adalah semua populasi yang tercantum di catatan rekam medis. Pengambilan sampel menggunakan teknik total sampling.

\section{HASIL}

Pasien tonsilitis kronis pada anak usia $<18$ tahun selama tahun 2013 sebanyak 70 penderita, tetapi data yang tersedia di bagian rekam medis hanya sebanyak 50 penderita.

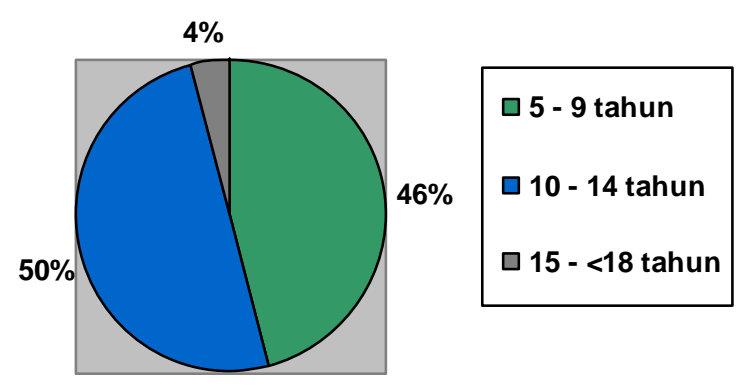

Gambar 1. Diagram persentase kelompok umur

Berdasarkan Gambar 1 didapatkan bahwa pasien Tonsilitis kronis pada anak paling banyak (50\%) terdapat pada kelompok umur 10 - 14 tahun.

Pada Tabel 1 didapatkan lebih dari separuh (56\%) pasien Tonsilitis Kronis pada anak adalah jenis kelamin perempuan.

Tabel 1. Distribusi frekuensi jenis kelamin

\begin{tabular}{ccc}
\hline Jenis Kelamin & f & $\%$ \\
\hline Laki - laki & 22 & 44 \\
Perempuan & 28 & 56 \\
\hline
\end{tabular}

\begin{tabular}{lll}
\hline Total & 50 & 100 \\
\hline
\end{tabular}

Berdasarkan Gambar 2 didapatkan bahwa keluhan utama paling banyak (64\%) pasien Tonsilitis Kronis pada anak adalah nyeri menelan berulang.

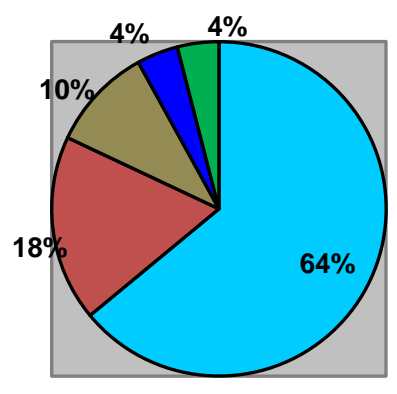

\begin{tabular}{|l|}
\hline anyeri menelan \\
berulang \\
arasa mengganjal \\
di tenggorok \\
tidur ngorok + \\
sesak nafas \\
bengkak pada \\
leher \\
nyeri telinga + \\
demam \\
\hline
\end{tabular}

Gambar 2. Diagram persentase keluhan utama

Gambar 3 memperlihatkan ukuran tonsil yang paling banyak (68\%) ditemukan pada anak yaitu ukuran T3 - T3, dan ukuran tonsil yang paling sedikit (2\%) ditemukan yaitu ukuran T4 - T3 dan T4 - T4.

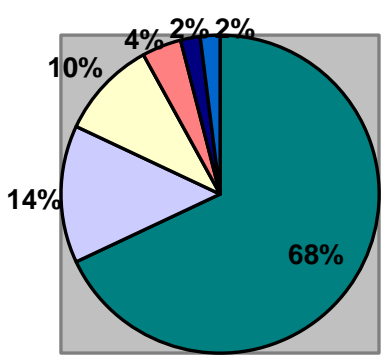

\begin{tabular}{|c|}
\hline 口T3 - T3 \\
\hline 口T2 - T2 \\
\hline 口T2 - T3 \\
\hline 口T3 - T2 \\
\hline -T4 - T3 \\
\hline 口T4 - T4 \\
\hline
\end{tabular}

Gambar 3. Diagram persentase ukuran tonsil Keterangan:

T3-T3 : tonsil kiri dan kanan telah melewati garis paramedian T2-T2 : tonsil kiri dan kanan telah melewati plika posterior

T2-T3: tonsil kiri telah melewati plika posterior dan tonsil kanan telah melewati garis paramedian

T3-T2: tonsil kiri telah melewati garis paramediandan tonsil kanan telah melewati plika posterior

T4-T3: tonsil kiri telah melewati garis median dan tonsil kanan telah melewati garis paramedian

T4-T4: kissing tonsil

Berdasarkan Tabel 2 didapatkan bahwa sebagian besar (88\%) penatalaksanaan Tonsilitis Kronis pada anak adalah dengan cara operatif.

Tabel 2. Distribusi frekuensi penatalaksanaan

\begin{tabular}{lll} 
Penatalaksanaan & f & $\%$ \\
\hline
\end{tabular}




\begin{tabular}{ccc}
\hline Medikamentosa & 6 & 12 \\
Operatif & 44 & 88 \\
\hline Total & 50 & 100 \\
\hline
\end{tabular}

\section{PEMBAHASAN}

Gambar 1

Pasien tonsilitis kronis pada anak paling banyak terdapat pada kelompok umur 10-14 tahun sebanyak 25 pasien (50\%). Hampir serupa dengan penelitian case series Sing tahun 2007 terhadap 657 pasien Tonsilitis yang berobat ke Poliklinik rawat jalan RS Serawak Malaysia, kelompok terbanyak pada umur $\leq 14$ tahun sebesar $58 \%$ sedangkan kelompok umur $>14$ tahun sebanyak 48\%. Penelitian Sapitri di RSUP Raden Mattaher Jambitahun 2013, pasien Tonsilitis Kronis terbanyak pada kisaran umur 5 - 14 tahun (50\%). Penelitian Khasanov et al di Rusia mengenai prevalensi tonsilitis kronis pada keluarga, didapatkan 335 orang anak usia 1-15 tahun dari 321 keluarga mengalami penyakit tonsilitis kronis. Pada penelitian Sembiring et al tahun 2013 di poliklinik THT BLU RSUP Prof dr. R. D. Kandou didapatkan usia terbanyak yang menderita Tonsilitis Kronis yaitu usia<12 tahun. Penelitian Farokah di 3 buah sekolah dasar yang dijadikan sampel di Semarang ditemukan usia anak yang terbanyak mengalami tonsilitis kronis pada usia 8 tahun $(69,8 \%)$. $8,10,11,13,14$

Terdapat banyak persamaan kisaran umur antara beberapa penelitian diatas yaitu antara umur 5-14 tahun. Banyak faktor yang menyebabkan tonsilitis kronis lebih sering terjadi pada usia anak. Aktivitas imunologi terbesar tonsil ditemukan pada usia 3 - 10 tahun. Gambaran respon imun selular pada tonsilitis kronis menunjukkan terjadinya peningkatan deposit antigen pada jaringan tonsil. Hal ini menyebabkan peningkatan regulasi sel-sel imunokompeten yang terjadi terus-menerus. Hal ini dibuktikan dengan adanya peningkatan insidensi sel yang mengekspresikan IL-1 $\beta$, TNF- $\alpha$, IL- 6 , IL-8, IL-2, INF-y, IL-10 dan IL-4. Pada usia sekolah, mulai dari usia 5 tahun, anak lebih rentan terkena infeksi virus dan bakteri dari lingkungan sekitar. Salah satu faktor predisposisi timbulnya tonsilitis kronis adalah pengaruh beberapa jenis makanan, hal ini disebabkan karena anak mengkonsumsi makanan seperti makanan dengan pemanis buatan, mengandung banyak pengawet dan perawatan mulut yang tidak baik. $^{3,4}$

\section{Tabel 1}

Tonsilitis kronis pada anak lebih banyak dijumpai pada jenis kelamin perempuan. Pada penelitian di RSUD Raden Mattaher Jambi didapatkan penderita tonsilitis kronis dengan usia mayoritas 5-14 tahun adalah perempuan 17 (56,7\%) dan laki-laki 13(43,3\%) . Pada tahun 2010, Kishve et al melakukan penelitian case series di India, dari 203 pasien tonsilitis dengan mayoritas usia 5-14 tahun lebih banyak berjenis kelamin perempuan yakni sebanyak 105 (51,72\%), sedangkan laki-laki sebanyak 98 $(48,28 \%)$. Hal ini sesuai dengan data dari prevalensi penyakit kronis Amerika Serikat, didapatkan rata-rata jumlah penderita tonsilitis kronis setiap tahunnya lebih banyak pada jenis kelamin perempuan yakni sebanyak 13,7/1.000 penduduk sedangkan laki-laki sebanyak 9/1.000 penduduk. ${ }^{9,11,15}$

Hasil yang berbeda didapatkan dari penelitian Sembiring et al tahun 2013 di poliklinik THT BLU RSUP Prof. dr. R. D. Kandou dari 20 sampel yang didapat, dengan usia mayoritas antara 1-12 tahun didapatkan jenis kelamin laki-laki sebanyak 55\%, sedangkan jenis kelamin perempuan $45 \%$. Begitu juga pada penelitian Ugras dan Ahmed, dari 120 pasien tonsillitis kronis, didapatkan 66(55\%) laki-laki dan $54(45 \%)$ perempuan. ${ }^{14,16}$

Ada perbedaan dari beberapa penelitian mengenai jenis kelamin yang dominan mengalami tonsilitis kronis. Pada penelitian Abouzied dan Emad terkait perbedaan jenis kelamin pada pasien tonsilitis kronis, dikemukakan beberapa teori mengenai perbedaan jenis kelamin pada kejadian Tonsilitis Kronis. Beberapa faktor yang ditelitinya adalah keterlibatan faktor genetik dan perbedaan budaya.

Hasil yang didapatkan dari penelitian ini ditemukan bahwa tidak adanya keterlibatan faktor genetik dan budaya pada perbedaan jenis kelamin yang sering mengalami tonsilitis kronis. Dapat disimpulkan bahwa belum ditemukan adanya faktor yang mempengaruhi perbedaan jenis kelamin pada tonsilitis kronis. Hal ini kemungkinan hanya pengaruh populasi dalam suatu penduduk terkait dominasi jenis 
kelamin tertentu terhadap kejadian tonsilitis kronis, baik laki-laki maupun perempuan. ${ }^{17}$

\section{Gambar 2}

Keluhan utama pasien tonsilitis kronis pada anak yang paling banyak ditemukan pada penelitian ini adalah nyeri menelan berulang sebanyak (64\%). Semua pasien dengan keluhan nyeri menelan berulang pada penelitian ini seluruhnya telah masuk ke dalam indikasi tonsilektomi oleh The American Academy of Otolaryngology - Head and Neck Surgery Clinical Indicators Compendium yaitu lebih dari tiga kali per tahun. Hasil penelitian ini sesuai dengan penelitian yang dilakukan Sapitri tahun 2013di RSUD Raden Mattaher Jambi, dari 30 pasien dengan usia mayoritas 5-14 tahun didapatkan keluhan utama terbanyak pasien tonsilitis kronis yang diindikasikan tonsilektomi adalah nyeri menelan/nyeri tenggorok (100\%). Hal ini terjadi karena peradangan pada tonsil sehingga menyebabkan keluhan tidak nyaman kepada pasien berupa rasa nyeri saat menelan karena sesuatu yang ditelan menyentuh daerah yang mengalami peradangan. Kejadian berulang itu dikarenakan penyembuhan yang tidak sempurna akibat serangan awal pada tonsil, sehingga bakteri patogen yang masih menetap pada tonsil sewaktu serangan pertama dapat sewaktu-waktu kembali menyerang tonsil apabila daya tahan tubuh mengalami penurunan. Serangan berulang dari bakteri patogen itulah yang menyebabkan keluhan berupa nyeri menelan berulang yang merupakan tanda telah terjadinya peradangan kronis. ${ }^{1,11}$

Beberapa keluhan lain seperti rasa mengganjal di tenggorok, tidur ngorok, sesak nafas, bengkak pada leher dan nyeri telinga serta demam dapat saja terjadi. Rasa mengganjal di tenggorok disebabkan karena peradangan pada tonsil yang akan mengakibatkan tonsil membesar dan dapat menyebabkan kesulitan menelan atau seperti ada yang mengganjal di tenggorok. Pada anak jika pembesaran tonsil telah menyebabkan obstruksi parsial atau total jalan nafas, hal tersebut dapat menyebabkan gangguan fisiologis berupa kesulitan bernafas saat tidur dan mendengkur, yang dikenal dengan istilah Obstructive Sleep Apnea Syndrome (OSAS). Infeksi pada tonsil juga dapat menyebabkan pembengkakan pada bagian leher, karena aliran getah bening dari daerah tonsil menuju ke rangkaian getah bening servikal profunda (deep jugular node) bagian superior di bawah $\mathrm{M}$. sternokleidomastoideus. Nyeri telinga dapat menjadi keluhan beberapa pasien, ini bisa terjadi akibat komplikasi dari infeksi pada tonsil sehingga mengakibatkan tersumbatnya saluran tuba eustachius yang akan berakibat terjadinya otitis media akut. Demam dapat terjadi karena respon tubuh akibat adanya antigen asing yang menyerang sistem pertahanan tubuh. ${ }^{1,3,18,19}$

\section{Gambar 3}

Ukuran tonsil pada anak yang paling banyak ditemukan pada penelitian ini yaitu ukuran T3 - T3 (68\%). Hasil ini sesuai dengan penelitian cross sectional Nikhlagh yang dikutip Amalia tahun 2011dari 812 penderita yang mendapatkan tindakan tonsilektomi, sebanyak 341 (42\%) dengan ukuran tonsil T3, sebanyak 308 (38\%) ukuran T4, sebanyak 130 (16\%) ukuran T2 dan sebanyak 33 (4\%) ukuran T1. Penelitian cross sectional Farokah terhadap 145 siswa usia 7-9 tahun yang menderita tonsilitis kronis, sebanyak 83 mempunyai ukuran tonsil T1 dan T2 sementara 62 siswa mempunyai ukuran tonsil T3 dan tidak ditemukan ukuran tonsil T4. Penelitian yang dilakukan di Denizli Turkey dari 1.784 anak sekolah usia 4-17 tahun didapatkan data ukuran tonsil terbanyak yakni T1: 1.119 (62\%), T2: 507 (28,4\%), T3: 58 (3,3\%), T4: 2 (0,1\%). ${ }^{10,20,21}$

Beberapa penelitian di atas memiliki perbedaan mengenai ukuran tonsil yang dominan ditemukan pada anak. Data pasti belum ditemukan kenapa terdapat perbedaan antara beberapa penelitian ini. Salah satu faktor pembesaran pada tonsil karena pengaruh infeksi pada tonsil. Ukuran tonsil membesar akibat hiperplasia parenkim atau degenerasi fibrinoid dengan obstruksi kripta tonsil. Infeksi yang berulang dan sumbatan pada kripta tonsil mengakibatkan peningkatan stasis debris maupun antigen di dalam kripta, juga terjadi penurunan integritas epitel kripta sehingga memudahkan bakteri masuk ke parenkim tonsil. Bakteri yang masuk ke dalam parenkim tonsil akan mengakibatkan terjadinya infeksi tonsil. Pada tonsilitis kronis bisa ditemukan bakteri yang berlipat ganda. Bakteri yang menetap di dalam kripta tonsil 
menjadi sumber infeksi yang berulang terhadap tonsil. $^{1,12}$

Tabel 2

Penatalaksanaan terbanyak tonsilitis kronis pada anak adalah dengan cara operatif (tonsilektomi/tonsiloadenoidektomi) yaitu sebanyak 44 pasien (88\%). Penatalaksanaan tonsilektomi sebanyak 14 pasien, sedangkan tonsiloadenoidektomi sebanyak 30 pasien. Terdapat perbedaan yang signifikan terkait tindakan tonsilektomi dan tonsiloadenoidektomi, hal ini kemungkinan dikarenakan letak dari tonsil dan adenoid yang berdekatan membentuk cincin Waldeyer yang merupakan salah satu pertahanan awal terhadap infeksi patogen, sehingga akan memudahkan terjadinya infeksi sekaligus pada keduanya. ${ }^{4}$

Di Indonesia, data nasional mengenai jumlah operasi tonsilektomi belum ada. Penelitian Sapitri tahun 2013 di RSUD Raden Mattaher Jambi, dari 30 sampel, semuanya diindikasikan tonsilektomi dengan indikasi absolut tonsilektomi sebanyak 8 pasien $(26,7 \%)$ dan indikasi relatif tonsilektomi sebanyak 22 pasien (73,3\%). ${ }^{11}$

Pada tonsilitis kronis terjadi penurunan fungsi imunitas tonsil. Penurunan fungsi ditunjukkan melalui peningkatan deposit antigen persisten pada jaringan tonsil sehingga terjadi peningkatan regulasi sel-sel imunokompeten berakibat peningkatan insiden sel yang mengekspresikan IL-1 $\beta$, TNF- $\alpha$, IL-6, IL-8, IL-2, INF-y, IL-10, dan IL-4. Karena hal tersebut, banyak manfaat dilakukannya tonsilektomi pada pasien tonsilitis kronis. Tetapi tindakan tonsilektomi tetap harus sesuai indikasi. Beberapa manfaat tonsilektomi seperti menurunkan angka kejadian nyeri menelan/ nyeri tenggorok, penurunan pemakaian antibiotik, menurunkan pemakaian fasilitas kesehatan dan meminimalkan beban ekonomi penderita tonsillitis. ${ }^{3}$

Hasil penelitian ini berbeda dengan yang dilakukan Amalia di RSUP H. Adam Malik Medan tahun 2011. Penatalaksanaan penderita tonsilitis kronis yang terbanyak adalah dengan medikamentosa sebanyak $67(83,8 \%)$, sedangkan penatalaksanaan operatif hanya sebanyak 13(16,2\%). Kontroversi seputar tonsilektomi telah lama terjadi, tetapi tetap merupakan tindakan yang paling banyak dilakukan.
Hal ini dikarenakan manfaat tonsilektomi dirasakan lebih banyak terutama terkait kasus tonsilitis kronis. ${ }^{3,20}$

\section{KESIMPULAN}

Pasien Tonsilitis Kronis pada anak paling banyak ditemukan antara umur 10-14 tahun. Pada anak paling banyak ditemukan pada jenis kelamin perempuan. Keluhan utama pasien Tonsilitis Kronis pada anak yang paling banyak adalah nyeri menelan berulang. Ukuran tonsil pasien Tonsilitis Kronis pada anak yang paling banyak yaitu ukuran tonsil T3-T3. Penatalaksanaan pasien Tonsilitis Kronis pada anak yang paling banyak adalah dengan cara operatif

\section{UCAPAN TERIMA KASIH}

Terima kasih kepada semua pihak atas bimbingan, bantuan dan motivasi dalam penelitian ini.

\section{DAFTAR PUSTAKA}

1. Brodsky L, Poje C. Tonsillitis, tonsillectomy, and adenoidectomy. Dalam: Bailey BJ, Johnson JT, Newlands SD, editor (penyunting). Head and Neck Surgery Otolaryngology. Philadelpia: Lippincott Williams \& Wilkins, 2006;4(1):1183-98

2. Adams GL, Lawrence RB, Peter AH. BOIES Buku Ajar Penyakit THT (terjemahan). Edisi Ke-6. Jakarta: EGC;1997. hlm.337-40.

3. Amarudin T, Anton C. Kajian manfaat tonsilektomi. Cermin Dunia Kedokteran. 2007;155:61-8.

4. Soepardi EA. Buku ajar ilmu kesehatan telinga hidung tenggorok kepala \& leher. Edisi Ke-6. Jakarta: Balai Penerbit FKUI;.2007.hlm. 223-25.

5. Khan AR, Khan SA, Arif AU, Waheed R. Analysis of ENT diseases at Khyber teaching hospital, Peshawar. J. Med. Sci. 2013;21(1):7-9.

6. Tarasov DI, Morozov AB. Frequency and structure of chronic disease of ear, throat and nose among population and their dinamycs. Vestn Otorino laryngology.1991; 2:12-4.

7. Edayu SN. Perbedaan tingkat kebersihan mulut terhadap kejadian tonsilitis kronik pada anak di Sekolah Dasar Negeri 060922 (skripsi). Medan: Fakultas Kedokteran Universitas Sumatera Utara; .2011 . 
8. Khasanov SA, Asrorov AA, Vokhidov UN. Prevalence of chronic family tonsilitis and its prevention. Vestn Otorinolaryngology. 2006;4:3840.

9. Kishve SP, Kumar N, Kishve PS, Aarif SMM, Kalakoti $P$. Ear, nose and throat disorders in paediatric patients at a rural hospital in India. Australasian Medical Journal. 2010;3(12):786-90.

10. Farokah. Hubungan tonsilitis kronik dengan prestasi belajar pada siswa kelas II sekolah dasar di Kota Semarang (skripsi). Semarang:Fakultas Kedokteran Universitas Diponegoro;2005.

11. Sapitri V. Karakteristik penderita tonsilitis kronis yang diindikasikan tonsilektomi Di RSUD Raden Mattaher Jambi (skripsi). Jambi: Fakultas Kedokteran dan IImu Kesehatan Universitas Jambi; 2013.

12. Novialdi N, Pulungan MR. Mikrobiologi tonsilitis kronis. Padang: Fakultas Kedokteran Universitas Andalas. Padang; .2010.

13. Sing TT. Pattern of otorhinolaryngology head and neck diseases in outpatient clinic of a Malaysian Hospital. Internet Journal of Head and Neck Surgery. 2007; 2(1).

14. Sembiring RO, John P, Olivia W. Identifikasi bakteri dan uji kepekaan terhadap antibiotik pada penderita tonsilitis di poliklinik THT-KL BLU RSU. Prof. Dr. R. D. Kandou Manado periode November 2012-Januari 2013. Manado: Fakultas Kedokteran Universitas Sam Ratulangi; .2013.

15. National Center for Health Statistic United State. Vital and health statistics, prevalence of selected chronic conditions. 1997. hlm.1-127.
16. Ugras S, Ahmed K. Chronic tonsillitis can be diagnosed with histopahologic findings. Eur J Gen Med. 2008;5(2):95-103.

17. Abouzied A, Emad M. Sex differences in tonsillitis. Dalhausie Medical Journal. 2008;35(1):8-10.

18. Supriyatno B, Rusmala D. Obstructive sleep apnea syndrome pada anak. Sari Pediatri. 2005;7(2):7784.

19. Sherwood L. Fisiologi manusia (terjemahan). Edisi Ke-2. Jakarta: EGC; .2001.hlm. 336-406.

20. Amalia N. Karakteristik penderita tonsilitis kronis di RSUP H. Adam Malik Medan tahun 2009 (skripsi). Medan: Fakultas Kedokteran Universitas Sumatera Utara; 2011.

21. Akcay A, Kara CO, Dagdefiren E, Zencir M. Variation in tonsil size in 4 to 17 years old schoolchildren. The Journal of Otolaryngology. 2006;35(4):270-4. 